The Huston Smith Reader 
The publisher gratefully acknowledges the generous support of the Humanities Endowment Fund of the University of California Press Foundation. 


\section{The Huston Smith Reader}

Edited, with an Introduction, by

Jeffery Paine

\section{따}

UNIVERSITY OF CALIFORNIA PRESS

Berkeley Los Angeles London 
University of California Press, one of the most distinguished university presses in the United States, enriches lives around the world by advancing scholarship in the humanities, social sciences, and natural sciences. Its activities are supported by the UC Press Foundation and by philanthropic contributions from individuals and institutions. For more information, visit www.ucpress.edu.

University of California Press

Berkeley and Los Angeles, California

University of California Press, Ltd.

London, England

(c) 2012 by Huston Smith

For acknowledgment of previous publication, please see credits, page 255 .

Library of Congress Cataloging-in-Publication Data

Smith, Huston.

The Huston Smith reader / edited with an introduction by Jeffery Paine.

p. $\mathrm{cm}$.

Includes bibliographical references.

ISBN 978-0-520-27022-o (cloth : alk. paper)

1. Religion. 2. Religions. I. Paine, Jeffery, 1944- II. Title.

BL27.S39 2012

$200-\mathrm{dc} 23$

2011030335

Manufactured in the United States of America

$\begin{array}{llllllllll}21 & 20 & 19 & 18 & 17 & 16 & 15 & 14 & 13 & 12\end{array}$

$\begin{array}{llllllllll}10 & 9 & 8 & 7 & 6 & 5 & 4 & 3 & 2 & 1\end{array}$

In keeping with a commitment to support environmentally responsible and sustainable printing practices, UC Press has printed this book on Rolland Enviro1oo, a 100\% post-consumer fiber paper that is FSC certified, deinked, processed chlorine-free, and manufactured with renewable biogas energy. It is acid-free and EcoLogo certified. 